\title{
ENDOSCOPIC MUCOSAL RESECTION OF EARLY GASTRIC CANCER: initial experience with two technical variants
}

\author{
Paulo Moacir de Oliveira CAMPOLI,2, Flávio Hayato EJIMA1, Daniela Medeiros Milhomem CARD0S01, \\ Eliane Duarte MOTA ${ }^{3}$, Ailton Cabral FRAGA Jr. ${ }^{3}$ and Orlando Milhomem da MOTA²
}

\begin{abstract}
Background - When performed in carefully selected cases, the endoscopic treatment of early gastric cancer yields results which are comparable to the conventional surgical treatment, but with lower morbidity and mortality and better quality of life. Several technical options to perform endoscopic mucosal resection have been described and there is a large amount of accumulated experience with this procedure in eastern countries. In western countries, particularly in Brazil, technical limitations associated with the small number of cases of early gastric cancer reflect the little experience with this therapeutic mode. Aim - This study was carried out in order to assess the indications, pathological results and morbidity of a series of endoscopic mucosal resections using two technical variants in addition to investigating the safety and feasibility of the method. Methods - Individuals with well-differentiated early gastric adenocarcinomas with up to $30 \mathrm{~mm}$ in diameter without scar or ulcer underwent endoscopic treatment. Two variants of the strip biopsy technique were used. The pathological study assessed the depth of the vertical invasion, lateral and basal margins as well as angio-lymphatic invasion. Results - Thirteen tumors in 12 patients were resected between June 2002 and August 2005. The most common macroscopic types were IIa and IIa + IIc. Tumor size ranged from 10 to $30 \mathrm{~mm}$ (mean $=16.5 \mathrm{~mm}$ ). En bloc resection was carried out in nine patients. Angio-lymphatic invasion was not observed; however, submucosal invasion was found in two cases. In four cases, the lateral margin was involved. Perforation occurred in two patients who then received conservative treatment. Conclusion - The relatively small series presented here suggests that the method is safe and feasible. Appropriate patient selection is the most important criteria. Long follow-up is required after treatment due to the risk of relapse. HEADINGS - Stomach neoplasms, surgery. Gastric mucosa. Endoscopy, gastrointestinal.
\end{abstract}

\section{INTRODUCTION}

Early gastric cancer is defined as a carcinoma that is confined to the mucosa or to the mucosa and submucosa regardless of metastases ${ }^{(16)}$. Throughout history, the treatment of early gastric cancer as well as advanced gastric cancer has been done in a similar way through gastrectomy with lymph node dissection ${ }^{(23)}$. The conventional surgical procedure presents morbidity rates ranging from $9.6 \%$ to $18.7 \% 0^{(33,43)}$ and mortality rates ranging from $2.1 \%$ to $9.2 \%{ }^{(30,33,43)}$. Several functions of the stomach become compromised following the resection, which in turn generates postgastrectomy syndromes that result in the worsening of these patients' life quality ${ }^{(35)}$. The aim of endoscopic mucosal resection (EMR) in early gastric cancer is to provide treatment which is as appropriate as the surgical one with lower morbidity and mortality and better quality of life.

Among the available technical options, the most widely used in several centers is the procedure called strip biopsy, described by TADA et al. ${ }^{(37)}$ in 1984 . This approach involves the submucosal injection of saline to elevate the mucosa, site of the neoplasia, followed by polypectomy snare resection under endoscopic guidance. Two other technical options are endoscopic mucosal resection with a cap-fitted endoscope (EMR-C) as described by INOUE et al. ${ }^{(13)}$ in 1993 and endoscopic mucosal resection using a ligating device (EMR-L) described in Brazil by CHAVES et al. ${ }^{(2)}$ in 1994. These technical procedures allow the resection of fragments with only 10 to $15 \mathrm{~mm}$ in diameter. Recent studies have demonstrated that endoscopic resection of tumors with up to $30 \mathrm{~mm}$ in diameter is adequate ${ }^{(6,29,42)}$; however, these three methods only allow piecemeal removal of tumors which exceed $15 \mathrm{~mm}$, a fact which makes the pathological study difficult, increases the risk of positive resection margin and local recurrence ${ }^{(20,22,24)}$.

The performance of strip biopsy with a one-channel endoscope is at times made more difficult due to the fact that the snare glides on the tumor. A good solution to this problem was put forth by HIRAO et al. ${ }^{(10)}$ in 1988 who described a technical variant called endoscopic resection with local injection of hypertonic saline epinephrine solution (ERHSE). The use of this solution aims at keeping the mucosa elevated during a larger period of time, which

\footnotetext{
Department of Digestive Endoscopy; ${ }^{2}$ Department of Gastrointestinal Oncology; ${ }^{3}$ Department of Pathology, "Araújo Jorge" Hospital of the Goiás Anticancer Association Goiânia, GO, Brazil.

Correspondence: Dr. Paulo Moacir de Oliveira Campoli - Avenida 85, 300 - apto. 504-C - Edifício Itatiaia - Setor Marista - 74160-010 - Goiânia, GO, Brazil. E-mail: paulomar@ih.com.br
} 
makes it possible to perform circumferential mucosal incision. These authors proposed the performance of circumferential incision using a needle-knife in order to allow the snare to anchor along the incision line and perform the resection of the tumor. This variant allows the use of a conventional singlechannel endoscope, the resection of larger tumors as well as the improvement of the control in achieving clear lateral margin. This technique has been used by other authors ${ }^{(3,17,22,40,41)}$, who have reported good results regarding en bloc resection of tumors larger than $15 \mathrm{~mm}$.

In 1998, HOSOKAWA and YOSHIDA ${ }^{(12)}$ developed a special endoscopic knife, called the insulation-tipped electrosurgical knife (IT knife), which consists of a conventional diathermic needle knife with a ceramic ball on top, in order to render its use safer and minimize the risk of perforation. Since then some centers in Japan have introduced a new technique called Endoscopic Submucosal Dissection (ESD), which consists in the circumferential mucosal incision followed by the dissection in the deeper part of the submucosa, along the muscularis propria. This procedure has allowed a more successful proposition of one-piece resection of larger tumors, thus reducing the risk of local recurrence ${ }^{(24,25,31,36)}$.

Since 2002 we have performed endoscopic resection of early gastric cancer using the technique proposed by TADA et al. ${ }^{(37)}$ (strip biopsy - Figure 1) and the technical variant proposed by HIRAO et al. ${ }^{(10)}$ (ERHSE), which involves the circumferential incision of the mucosa around the tumor (Figure 2).

The aim of the present study was to assess the indications, pathological results and morbidity in a series of EMR comparing these two technical variants in addition to investigating the safety and feasibility of this method.

\section{METHOD}

The patients with gastric adenocarcinoma cared for at the Department of Gastrointestinal Oncology of the "Araújo Jorge" Hospital of the Goiás Anticancer Association, Goiânia, GO, Brazil, who presented clinical and endoscopic elements suggestive of early gastric cancer were referred to the Department of Digestive Endoscopy for assessment of the indication of endoscopic treatment.

The patients included were those whose tumors had endoscopic characteristics classifiable as early, with up to $30 \mathrm{~mm}$ in diameter, without scar or ulcer. Cases for which the endoscopic biopsies of had demonstrated undifferentiated carcinoma were excluded. All of the tumors were classified according with the Japanese classification of gastric carcinoma ${ }^{(14)}$.

All the patients were informed as to the risks and benefits of the proposed procedure and an informed consent was obtained.

EMR was performed under an outpatient regime in the digestive endoscopic room, under conscious sedation, and a conventional single-channel endoscope was used. The patients were monitored through pulse oximetry and received supplementary oxygen when necessary. In all cases chromoscopy was performed using $0,2 \%$ indigo carmine solution so that we could obtain a better definition of the lesion dimension and macroscopic classification.
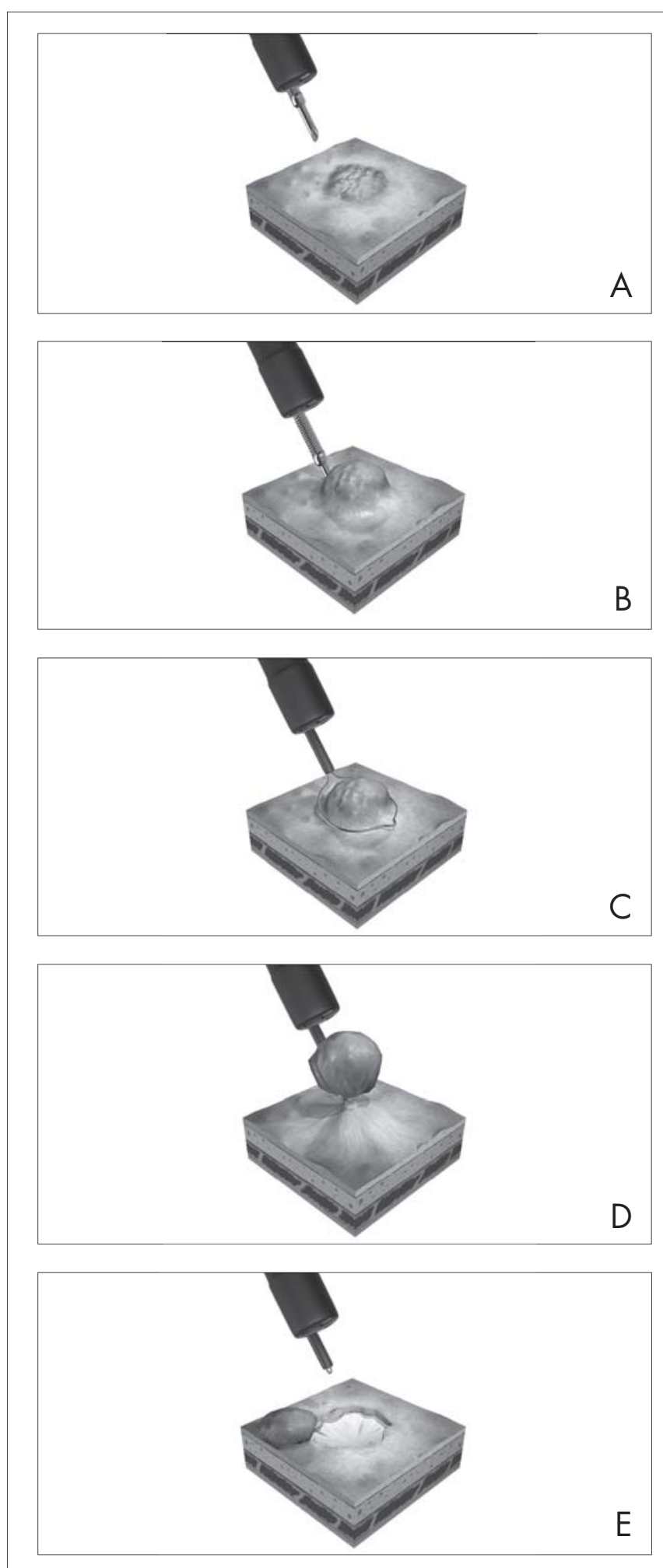

FIGURE 1. Strip biopsy technique. A and B - Submucosal layer injection of hypertonic saline solution with an injection needle. $\mathrm{C}$ to $\mathrm{E}-$ Tumor snaring and resection 


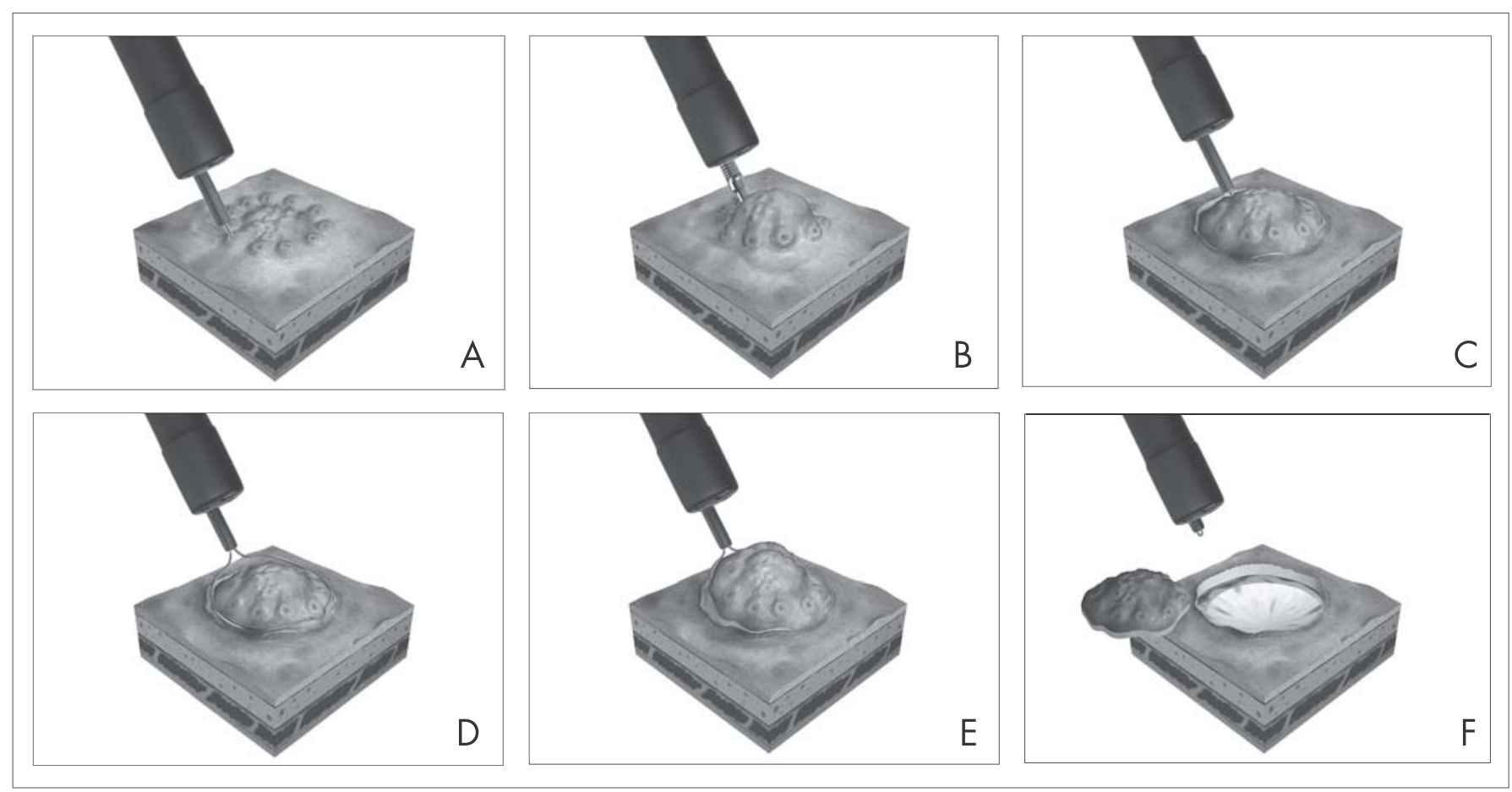

FIGURE 2. ERHSE technique. A - Defining tumor boundaries. B - Submucosal layer injection of hypertonic saline epinephrine solution with an injection needle. C - Performance of circumferential incision with a needle knife. D - Anchoring of snare at the circumferential incision. $\mathrm{E}$ and $\mathrm{F}$ - Snaring and resection of tumor

Endoscopic ultrasonography was not used for staging in the current series.

The strip biopsy technique was performed through a submucosal layer injection of $5.0 \%$ hypertonic saline solution (Figures 1a and $1 \mathrm{~b}$ ) with an injection needle (NM-4L-1 Olympus, Japan). We used a snare (SD-9L-1 - Olympus, Japan - Figure 1c) and an electrosurgical unit with blended cut and coagulation current mode (B1600MP - Deltronix Eq Ltd., Ribeirão Preto, SP, Brazil) to resect the lesion (Figures 1d and 1e).

The ERHSE technique was performed through the establishment of the tumor boundaries (Figure 2a) followed by a submucosal layer injection of $5.0 \%$ saline epinephrine $(1: 20,000)$ solution (Figure 2b) with an injection needle (NM-4L-1 Olympus, Japan) and the circumferential incision (Figure 2c) was performed with a needle knife (OK 110 18N - ENDO-FLEX GmbH, Voerde, Germany). After that a snare (SD-9L-1 - Olympus, Japan) and electrosurgical generators with blended cut and coagulation current mode (B1600MP - Deltronix Eq Ltd., Ribeirão Preto, SP, Brazil) were used to resect the tumor (Figures $2 \mathrm{~d}$ to $2 \mathrm{f}$ ).

The resected specimens were stretched and fixed in $10 \%$ formalin and then sectioned at every $2 \mathrm{~mm}$. A pathological study was carried out in order to assess the histological type, differentiation, invasion depth, compromising of lateral and deep margins, angio-lymphatic invasion and presence of ulceration. All histological sections were reviewed by one single pathologist (EDM).

Resection was considered incomplete when the margins could not be evaluated or were microscopically positive.
Student's $t$-test was used to compare the differences in mean tumor size between the strip biopsy and the ERHSE groups. Fisher's exact test was used to compare the differences between en bloc resection rates and complete resection rates in the two groups. A $P$ value of less than 0.05 was considered to indicate statistical significance.

\section{RESULTS}

The present study includes 13 consecutive EMR performed on 12 patients with early gastric cancer between June 2002 and August 2005.

Among the 13 resected tumors, the predominance found was 5 cases of macroscopic type IIa, followed by 4 cases of type IIa + IIc, 2 cases of type IIc, 1 case of type I and 1 case of type IIb. The group consisted of seven men and five women, ranging in age from 37 to 81 years (median 71 years). The site of the tumors were the gastric antrum (seven cases) and the gastric body (six cases) and their size ranged from 10 to $30 \mathrm{~mm}($ mean $=16.5 \mathrm{~mm})$ (Table 1$)$. All tumors were well-differentiated adenocarcinomas.

Of the 13 resections, 7 were performed by using the strip biopsy and 6 by using the ERHSE technique. En bloc resection was performed in nine cases. The pathological study of the sections demonstrated that the tumors were limited to the mucosa in 11 cases and invaded the submucosa in the other two cases $(200 \mu \mathrm{m}$ e $500 \mu \mathrm{m})$. Angio-lymphatic invasion was not observed. The deep margin was tumor-free in all cases; however, the lateral margin was positive in four cases (Table 2). Of these four cases 
with positive margins, two were submitted to gastrectomy and the other were not operated on because of patient refusal or overtly high risk of cardiologic complication.

The statistical data analysis showed no significant difference between the two resection methods with regard to tumor size, en bloc resection rates and complete resection rates (Table 3 ).

Morbidity related to the procedure was constituted of two cases of gastric perforation highlighted by the formation of a large pneumoperitoneum diagnosed by conventional X-ray without clinical symptoms. Both were successfully treated through fasting and nasogastric tube during 3 days. Oral feeding was started on the 4th day and patients were discharged on the 5th day following hospitalization. Antibiotic therapy was maintained during 10 days.

TABLE 1. Clinical and endoscopic characteristics of the patients

\begin{tabular}{|c|c|c|c|c|c|}
\hline Tumor type & $\mathrm{n}$ & Sex & Age & Localization & Size $(\mathrm{mm})$ \\
\hline \multirow{5}{*}{ IIa } & \multirow{5}{*}{5} & male & 65 & antrum & 15 \\
\hline & & female* & 65 & body & 20 \\
\hline & & male & 78 & antrum & 20 \\
\hline & & male & 75 & antrum & 20 \\
\hline & & male & 76 & body & 20 \\
\hline \multirow{4}{*}{$\mathrm{IIa}+\mathrm{IIC}$} & \multirow{4}{*}{4} & female* & 65 & antrum & 10 \\
\hline & & female & 81 & antrum & 12 \\
\hline & & female & 37 & antrum & 15 \\
\hline & & male & 79 & body & 15 \\
\hline \multirow{2}{*}{ IIc } & \multirow{2}{*}{2} & female & 71 & antrum & 10 \\
\hline & & female & 64 & body & 12 \\
\hline I & 1 & male & 76 & body & 30 \\
\hline IIb & 1 & male & 61 & body & 15 \\
\hline Total & 13 & $\begin{array}{c}\text { male: } 7 \\
\text { female*: } 5\end{array}$ & $\begin{array}{c}37-81 \\
\text { median: } 71\end{array}$ & $\begin{array}{c}\text { antrum: } 7 \\
\text { body: } 6\end{array}$ & $\begin{array}{c}10-30 \\
\text { mean: } 16.5\end{array}$ \\
\hline
\end{tabular}

*One of the patients had two synchronic tumors (types $\|$ a and $\|a+\| c \mid$
TABLE 3. Analysis of pathologic features between the two resection methods

\begin{tabular}{lccc}
\hline & Strip biopsy & ERHSE & $P$ value \\
\hline Mean size [sd] & $18.1[ \pm 6.6] \mathrm{mm}$ & $14.5[ \pm 3.3] \mathrm{mm}$ & $0.125(\mathrm{~ns})$ \\
En bloc & $71 \%(5 / 7)$ & $66 \%(4 / 6)$ & $0.657(\mathrm{~ns})$ \\
& & & \\
Complete resection & $85 \%(6 / 7)$ & $50 \%(3 / 6)$ & $0.217(\mathrm{~ns})$ \\
\hline
\end{tabular}

\section{$\mathrm{sd}=$ standard deviatio}

$\mathrm{ns}=$ nonsignificant

\section{DISCUSSION}

The gain of knowledge of the indication of EMR in early gastric cancer associated with the development of new techniques has allowed an increasingly wider use of these methods in large centers worldwide ${ }^{(36)}$

Age-standardized incidence rates in Japan are quite high (61.8 for 100,000 men and 23.8 for 100,000 women) $)^{(1)}$. Furthermore, in Japan over $50 \%$ of diagnosed cases of gastric cancer are early type ${ }^{(31)}$. Such high rates yield a large number of patients with early gastric cancer, over $50 \%$ of which are currently treated via the endoscopic method in Japan ${ }^{(31)}$.

In our country the incidence rate of gastric cancer is lower than that found in eastern countries. The Population-based Cancer Registry of Goiânia refers to an incidence of 21.7 for 100,000 men and 9.4 for 100,000 women $^{(4)}$, and these rates are typical of average incidence for stomach neoplasias ${ }^{(27)}$. In Brazil, less than $15 \%$ of diagnosed cases of gastric cancer are early type ${ }^{(8,15,21,26)}$.

The small number of cases associated with the lack of technical resources in most of our country's centers renders the experience with endoscopic resection of early gastric cancer quite limited. To the best of the author's knowledge, the largest experience belongs to both the "Hospital das Clínicas" of the University of São Paulo Medical School, São Paulo, SP, and the "Hospital

TABLE 2. Histopathological evaluation of endoscopically resected specimens

\begin{tabular}{|c|c|c|c|c|c|}
\hline Size $(\mathrm{mm})$ & Technique & En-bloc & $\begin{array}{l}\text { Depth of } \\
\text { invasion }\end{array}$ & $\begin{array}{l}\text { Lateral } \\
\text { margin }\end{array}$ & $\begin{array}{l}\text { Vertical } \\
\text { margin }\end{array}$ \\
\hline 10 & Strip biopsy & Yes & mucosal & negative & negative \\
\hline 10 & ERHSE & No** & mucosal & negative & negative \\
\hline 12 & ERHSE & Yes & mucosal & negative & negative \\
\hline 12 & Strip biopsy & Yes & mucosal & positive & negative \\
\hline 15 & ERHSE & Yes & mucosal & positive & negative \\
\hline 15 & ERHSE & Yes & mucosal & positive & negative \\
\hline 15 & ERHSE & No* & mucosal & positive & negative \\
\hline 15 & Strip biopsy & Yes & submucosal & negative & negative \\
\hline 20 & ERHSE & Yes & mucosal & negative & negative \\
\hline 20 & Strip biopsy & No** & mucosal & negative & negative \\
\hline 20 & Strip biopsy & Yes & mucosal & negative & negative \\
\hline 20 & Strip biopsy & No* & mucosal & negative & negative \\
\hline 30 & Strip biopsy & Yes & submucosal & negative & negative \\
\hline
\end{tabular}

* two fragments

** three fragments 
das Clínicas" of the University of São Paulo Medical School at Ribeirão Preto, SP, Brazil. In the former institution, 31 cases were treated by mucosectomy between 1994 to 2000 using a two-channel therapeutic endoscope ${ }^{(34)}$. In the latter, 18 patients were treated by either polypectomy or mucosectomy between 1971 and $2003^{(26)}$. The series of cases presented here reflects the initial experience in a tertiary referral oncologic hospital, where the good integration between the Department of Surgical Oncology and the Department of Digestive Endoscopy brings forth a considerable large number of cases for which endoscopic resection is likely to be an alternative.

The use of a single-channel endoscope brings about important limitations in the performance of an EMR. The performance of strip biopsy with a single-channel front-viewing endoscope is generally possible only when the tumor is perpendicularly positioned to the endoscope. In cases in which the endoscope is in a parallel position to the tumor, involving it is only possible with the snare following the circumferential section with a needle-knife ${ }^{(22)}$. KOJIMA et al. ${ }^{(19)}$ compiled several publications involving 1832 EMR and found that in 1447 (79\%) opportunities double-channel endoscopes were used. Although the lack of double channel endoscopes at our institution causes greater difficulties, it does not render the performance of EMR unfeasible.

Another important technical item regards electrosurgical generators. The centers with large experience in performing EMR in early gastric cancer use electrosurgical generators with endocut current mode ${ }^{(25,40)}$. The use of this type of equipment is important in advanced endoscopic procedures as it is safe and yields improved accuracy and cut quality with lower risk of bleeding $^{(18,32)}$. The equipment made in Brazil we used did not feature this function and investments must be made in order to provide such technical resources.

The indications of EMR in early gastric cancer have undergone changes throughout the last years. In the early 90s, indications were restricted to well differentiated tumors without ulcer and limited to the mucosal layer, smaller than $20 \mathrm{~mm}$ for the IIa type and smaller than $10 \mathrm{~mm}$ for the IIc type ${ }^{(9,38,39)}$. In the last 10 years studies have shown that the risk of lymph node metastases is almost null in patients with tumor measuring up to $30 \mathrm{~mm}$ as long as they are well differentiated, ulcer-free and bearing no angio-lymphatic invasion, both in those limited to the mucosal layer ${ }^{(6,31,42)}$, and in those with invasion of the submucosal layer up to $500 \mu \mathrm{m}^{(6,29)}$. In the present study, all cases met these extended indication criteria. Some authors indicate endoscopic ultrasonography (EUS) before performing EMR in order to obtain a precise staging. It is a useful tool to evaluate early gastric lesions although it offers a limited accuracy of $80 \%-85 \%$ for staging, which means that $15 \%-20 \%$ of the patients may undergo inadequate staging ${ }^{(5,11)}$. Only the histological assessment of the resected material can give an adequate staging. The criteria to indicate EMR presented by several authors include size of the lesion, its differentiation degree and the macroscopic classification, without any reference to the use of the EUS to proceed with the

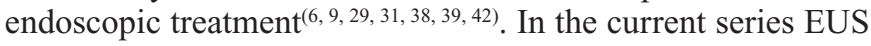
was not used for staging.

On the one hand, the expansion of the criteria for the local treatment broadened the spectrum of the performance of endoscopic treatment; on the other hand, it added technical difficulties for the performance of the procedure, especially in larger tumors. In order to face such difficulties, new techniques have been described aiming at the improvement of complete and en bloc resection rates ${ }^{(25,28,40,41)}$. Table 4 shows complete and en bloc resection rates published over the last years. As far as the small number of cases in the present series is concerned, the rates presented here are within acceptable limits and did not suffer any influence of the technical variant used (Table 3).

The main complications of EMR are bleeding and perforation. Bleeding is an infrequent event (Table 4) and is controllable with local measures using endoscopic methods. Likewise, gastric perforations diagnosed during the procedure are treated with a hemoclip and small gastric perforations, diagnosed by conventional $\mathrm{X}$-ray are treated conservatively and successfully.

The large series in the literature report perforation rates lower than $5 \%^{(3,10,24,31,40)}$. In the present series, two cases of perforation are reported, which represents $15.3 \%$ and becomes a high rate when compared with studies involving a large number of cases. On the other hand, the observation made by CHOI et al. ${ }^{(3)}$, should be taken into account as it states that the perforation rates in his first 20 cases was $15 \%$ and then dropped to $1.7 \%$ in the next 60 cases of EMR, clearly demonstrating that there is a learning curve to be covered. Similarly, MIYAZAKI et al. ${ }^{(25)}$, also report an $11.5 \%$ perforation rate in his first 29 cases (Table 4).

TABLE 4. Procedure-related complication rates

\begin{tabular}{|c|c|c|c|c|c|c|}
\hline Author & Year & $\mathrm{n}$ & $\begin{array}{l}\text { Complete } \\
\text { Resection }\end{array}$ & En bloc & Bleeding & Perforation \\
\hline ONO et al.(31) & 2001 & 479 & $69 \%$ & NA & 0 & $5.2 \%$ \\
\hline MIYAMOTO et al.(24) & 2002 & 123 & $41.5 \%$ & $54.5 \%$ & 0 & $0.8 \%$ \\
\hline YAMAMOTO et al.(41) & 2002 & 70 & $77 \%$ & $76 \%$ & $4 \%$ & 0 \\
\hline YAHAGI et al.(40) & 2004 & 59 & $96.6 \%$ & $95 \%$ & $1.7 \%$ & $3.4 \%$ \\
\hline NAGANO et al.(28) & 2005 & 726 & $52.1 \%$ & $72.9 \%$ & NA & NA \\
\hline MIYAZAKI et al.(25) & 2005 & 29 & $93 \%$ & $93 \%$ & $11.5 \%$ & $11.5 \%$ \\
\hline CHOI et al.(3) & 2005 & 80 & $75 \%$ & $67.5 \%$ & $3.7 \%$ & $5 \%$ \\
\hline CHOI et al.(3)* & 2005 & $20 *$ & $65 \%$ & $55 \%$ & $5 \%$ & $15 \%$ \\
\hline Current series & 2006 & 13 & $69.2 \%$ & $69.2 \%$ & 0 & $15.3 \%$ \\
\hline
\end{tabular}

* Rates related to the 20 first cases of a series of 80 cases 
The occurrence of bleeding and perforation causes major concern to the medical team; however, they are not burdened by greater severity once they are almost invariably effectively well controlled with conservative measures. Currently, the experts' major concern lies not only in safety but also in the efficacy of the endoscopic treatment ${ }^{(7)}$. Hence, the adequate indication and complete resection of the tumor should be the main goals to be achieved.

\section{CONCLUSION}

This is an efficient, safe and elegant procedure in the treatment of early gastric cancer as long as it is adequately indicated and performed with the appropriate technique.
Rigorous pathological study of the resected specimen and careful follow up are also required.

Our results have demonstrated that the method is both safe and feasible. The relatively small series presented here represents an initial experience which shall be adequately followed up in order to investigate long term results, especially with regard to local recurrence and overall survival.

\section{ACKNOWLEDGMENT}

We are grateful to Adriano Augusto Peclat de Paula for expert review of the manuscript and statistical analysis, and to Maria Paula Curado for statistical analysis.

Campoli PMO, Ejima FH, Cardoso DMM, Mota ED, Fraga Jr AC, Mota OM. Mucosectomia endoscópica no câncer gástrico precoce: experiência inicial com duas variantes técnicas. Arq Gastroenterol. 2007;44(3):250-6.

RESUMO - Racional - O tratamento endoscópico do câncer gástrico precoce quando realizado em casos bem selecionados proporciona resultados comparáveis ao tratamento cirúrgico convencional, porém com menor morbidade, menor mortalidade e melhor qualidade de vida. Diversas opções técnicas para a realização de ressecção endoscópica mucosa já foram descritas e há grande experiência acumulada nos países orientais com este procedimento. Nos países ocidentais, em particular no Brasil, as limitações técnicas associadas ao pequeno número de casos de câncer gástrico precoce se refletem na pequena experiência com esta modalidade terapêutica. Objetivo - Avaliar as indicações, resultados histopatológicos e morbidade de uma série de ressecções mucosas endoscópicas utilizando duas variantes técnicas, além de verificar a segurança e exeqüibilidade do método. Método - Pacientes com adenocarcinomas gástricos precoces e bem diferenciados, com até $30 \mathrm{~mm}$ de diâmetro, sem cicatriz ou úlcera foram submetidos a tratamento endoscópico. Foram utilizadas duas variantes técnicas de "strip biopsy". O estudo histopatológico avaliou a profundidade de invasão, margens laterais e profundas além da invasão angiolinfática. Resultados - Foram ressecadas 13 lesões em 12 pacientes no período de junho de 2002 a agosto de 2005. Os tipos macroscópicos mais comuns foram IIa e IIa + IIc. O tamanho das lesões variou de 10 a $30 \mathrm{~mm}$ (média de 16,5 mm). A ressecção foi efetuada em monobloco em nove casos. Não foi observada invasão angiolinfática, porém em duas oportunidades havia acometimento da camada submucosa. Quatro lesões tinham comprometimento da margem lateral. Dois pacientes apresentaram perfuração gástrica e foram tratados de forma conservadora. Conclusão - A série relativamente pequena aqui apresentada demonstra que o método é seguro e exeqüível, quando realizado em pacientes adequadamente selecionados. É necessário que estes sejam mantidos sob estreita vigilância para verificação dos resultados em longo prazo, especialmente em relação à recidiva local.

DESCRITORES - Neoplasias gástricas, cirurgia. Mucosa gástrica. Endoscopia gastrointestinal. 


\section{REFERENCES}

1. Ajiki W, Tsukuma H, Oshima A, Research group for population-based cancer registration in Japan. Cancer incidence and incidence rates in Japan in 1999: estimates based on data from 11 population-based cancer registries. Jpn J Clin Oncol. 2004;34:352-6.

2. Chaves DM, Sakai P, Mester M, Spinosa SR, Tomishige T, Ishioka S. A new endoscopic technique for the resection of flat polypoid lesions. Gastrointest Endosc. 1994;40 (2 Pt 1):224-6.

3. Choi IJ, Kim CG, Chang HJ, Kim SG, Kook MC, Bae JM. The learning curve for EMR with circumferential mucosal incision in treating intramucosal gastric neoplasm. Gastrointest Endosc. 2005;62:860-5.

4. Curado MP, Latorre MR, Bandeira CM. Brazil, Goiânia. In: Parkin DM, Whelan SL, Ferlay J, Teppo L, Thomas DB, editors. Cancer Incidence in Five Continents V. VIII. Lion: IARC Scientific Publications; 2002. p.112-3.

5. Ganpathi IS, So JB, Ho KY. Endoscopic ultrasonography for gastric cancer: does it influence treatment? Surg Endosc. 2006;20:559-62.

6. Gotoda T, Yanagisawa A, Sasako M, Ono H, Nakanishi Y, Shimoda T, Kato Y. Incidence of lymph node metastasis from early gastric cancer: estimation with a large number of cases at two large centers. Gastric Cancer. 2000;3:219-25.

7. Gotoda T, Friedland S, Hamanaka H, Soetikno R. A learning curve for advanced endoscopic resection. Gastrointest Endosc. 2005;62:866-7.

8. Henry MA, Saad LH, Goncalves Junior I, Bozoni LL. Gastric cancer: the analysis of the results of the surgical treatment. ABCD Arq Bras Cir Dig. 1991;6:82-5.

9. Hiki Y, Shimao H, Mieno H, Sakakibara Y, Kobayashi N, Saigenji K. Modified treatment of early gastric cancer: evaluation of endoscopic treatment of early gastric cancers with respect to treatment indication groups. World J Surg. 1995;19:517-22.

10. Hirao M, Masuda K, Asanuma T, Naka H, Noda K, Matsuura K, Yamaguchi O, Ueda $\mathrm{N}$. Endoscopic resection of early gastric cancer and other tumors with local injection of hypertonic saline-epinephrine. Gastrointest Endosc. 1988;34:264-9.

11. Hizawa K, Iwai K, Esaki M, Matsumoto T, Suekane H, Iida M. Is endoscopic ultrasonography indispensable in assessing the appropriateness of endoscopic resection for gastric cancer? Endoscopy. 2002;34:973-8.

12. Hosokawa $\mathrm{K}$, Yoshida $\mathrm{S}$. [Recent advances in endoscopic mucosal resection for early gastric cancer] Gan To Kagaku Ryoho. 1998;25:476-83.

13. Inoue H, Takeshita K, Hori H, Muraoka Y, Yoneshima H, Endo M. Endoscopic mucosal resection with a cap-fitted panendoscope for esophagus, stomach, and colon mucosal lesions. Gastrointest Endosc. 1993;39:58-62.

14. Japanese Gastric Cancer Association. Japanese Classification of Gastric Carcinoma 2nd English Edition. Gastric Cancer. 1998;1:10-24.

15. Jacob CE. [Early gastric cancer: clinical and pathologic features; correlation with late survival]. [tese]. São Paulo: Universidade de Säo Paulo. Faculdade de Medicina. Departamento de Gastroenterologia; 2003.

16. Kajitani $\mathrm{T}$. The general rules for the gastric cancer study in surgery and pathology. Part I. Clinical classification. Jpn J Surg. 1981;11:127-39.

17. Katsube T, Ogawa K, Hamaguchi K, Shimao K, Yamaguchi K, Konno S, Shimakawa T, Naritaka Y, Yagawa H, Aiba M. Modification of endoscopic aspiration mucosectomy (EAM) for early gastric cancer: EAM with pre-cutting. Hepatogastroenterology. 2002;49:1510-3.

18. Kohler A, Maier M, Benz C, Martin WR, Farin G, Riemann JF. A new HF current generator with automatically controlled system (Endocut mode) for endoscopic sphincterotomy--preliminary experience. Endoscopy. 1998;30:351-5.

19. Kojima T, Parra-Blanco A, Takahashi H, Fujita R. Outcome of endoscopic mucosal resection for early gastric cancer: review of the Japanese literature. Gastrointes Endosc. 1998;48:550-4

20. Makuuchi H, Kise Y, Shimada H, Chino O, Tanaka H. Endoscopic mucosal resection for early gastric cancer. Semin Surg Oncol. 1999;17:108-16.

21. Marchesini JB, Brenner S, Buffara Júnior VA, Moreira M. [Early gastric cancer: analysis of 12 cases]. Rev Bras Cir. 1992;82:77-81.

22. Matsushita M, Hajiro K, Okazaki K, Takakuwa H. Endoscopic mucosal resection of gastric tumors located in the lesser curvature of the upper third of the stomach. Gastrointest Endosc. 1997:45:512-5.

23. Miwa K, Miyazaki I, Sahara H, Fujimura T, Yonemura Y, Noguchi M, Falla R. Rationale for extensive lymphadenectomy in early gastric carcinoma. Br J Cancer. $1995 ; 72: 1518-24$

24. Miyamoto S, Muto M, Hamamoto Y, Boku N, Ohtsu A, Baba S, Yoshida M, Ohkuwa M, Hosokawa K, Tajiri H, Yoshida S. A new technique for endoscopic mucosal resection with an insulated-tip electrosurgical knife improves the completeness of resection of intramucosal gastric neoplasms. Gastrointest Endosc. 2002;55:576-81.
25. Miyazaki S, GunjiY, Aoki T, Nakajima K, Nabeya Y, Hayashi H, Shimada H, Uesato M, Hirayama N, Karube T, Akai T, Nikaidou T, Kouzu T, Ochiai T. High en bloc resection rate achieved by endoscopic mucosal resection with IT knife for early gastric cancer. Hepatogastroenterology. 2005;52:954-8.

26. Módena, JL. [Câncer gástrico precoce]. In: Magalhães AF, Cordeiro FT, Quilici FA, Machado G, Amarante HM, Prolla JC, Leitão OR, Alves PR, Sakai P, editores. Endoscopia digestiva - diagnóstica e terapêutica. Rio de Janeiro: Revinter; 2005. p.338-55.

27. Moss SF, Shirin $\mathrm{H}$. Epidemiology and molecular epidemiology of gastric cancer. In Abbruzzese JL, Evans DB, Willett CG and Fenoglio-Preiser C, editors. Gastrointestinal oncology. New York: Oxford University Press; 2004. p.257-67.

28. Nagano H, Ohyama S, Fukunaga T, Seto Y, Fujisaki J, Yamaguchi T, Yamamoto N, Kato Y, Yamaguchi A. Indications for gastrectomy after incomplete EMR for early gastric cancer. Gastric Cancer. 2005;8:149-54.

29. Nakahara K, Tsuruta O, Tateishi H, Arima N, Takeda J, Toyonaga A, Sata M. Extended indication criteria for endoscopic mucosal resection of early gastric cancer with special reference to lymph node metastasis--examination by multivariate analysis. Kurume Med J. 2004;51:9-14.

30. Nanthakumaran S, Fernandes E, Thompson AM, Rapson T, Gilbert FJ, Park KG. Morbidity and mortality rates following gastric cancer surgery and contiguous organ removal, a population based study. Eur J Surg Oncol. 2005;31:1141-4.

31. Ono H, Kondo H, Gotoda T, Shirao K, Yamaguchi H, Saito D, Hosokawa K, Shimoda T, Yoshida S. Endoscopic mucosal resection for treatment of early gastric cancer. Gut. 2001;48:225-9.

32. Perini RF, Sadurski R, Cotton PB, Patel RS, Hawes RH, Cunningham JT. Postsphincterotomy bleeding after the introduction of microprocessor-controlled electrosurgery: does the new technology make the difference? Gastrointest Endosc. 2005;61:53-7.

33. Potrc S, Kavalar R, Hajdinjak T, Horvat M, Vidovic D, Gadzijev E. What have we learned from surgical treatment of gastric adenocarcinoma? A comparison of two periods. Wien Klin Wochenschr. 2004;116 (Suppl 2):56-9.

34. Sakai P, Chaves DM, Kuga R. [Estado atual da terapêutica endoscópica dos carcinomas iniciais do esôfago e do estômago]. In: Castro LP, Savassi-Rocha PR, Rodrigues MAG, Murad AM, editores. Tópicos em gastroenterologia. Rio de Janeiro: Medsi; 2002. p.125-40.

35. Schölmerich J. Postgastrectomy syndromes--diagnosis and treatment. Best Pract Res Clin Gastroenterol. 2004;18:917-33.

36. Soetikno R, Kaltenbach T, Yeh R, Gotoda T. Endoscopic mucosal resection for early cancers of the upper gastrointestinal tract. J Clin Oncol. 2005;23:4490-8.

37. Tada M, Murata M, Murakami F, Shimada M, Okazaki Y, Takemoto T, Iida Y [Development of the strip-off biopsy]. Gastroenterol Endosc. 1984;26:833-9.

38. Tada M, Murakami A, Karita M, Yanai H, Okita K. Endoscopic resection of early gastric cancer. Endoscopy. 1993;25:445-50.

39. Takekoshi T, Baba Y, Ota H, Kato Y, Yanagisawa A, Takagi K, Noguchi Y. Endoscopic resection of early gastric carcinoma: results of a retrospective analysis of 308 cases. Endoscopy. 1994;26:352-8.

40. Yahagi N, Fujishiro M, Kakushima N, Kobayashi K, Hashimoto T, Oka M, Iguchi M, Enomoto S, Ichinose M, Niwa H, Omata M. Endoscopic submucosal dissection for early gastric cancer using the tip of an electrosurgical snare (thin type). Dig Endosc. 2004;16:34-8.

41. Yamamoto H, Kawata H, Sunada K, Satoh K, Kaneko Y, Ido K, Sugano K. Success rate of curative endoscopic mucosal resection with circunferential mucosal incision assisted by submucosal injection of sodium hyaluronate. Gastrointest Endosc. 2002;56:507-12

42. Yamao T, Shirao K, Ono H, Kondo H, Saito D, Yamaguchi H, Sasako M, Sano T, Ochiai A, Yoshida S. Risk factors for lymph node metastasis from intramucosal gastric carcinoma. Cancer. 1996;77:602-6.

43. Zhang XF, Huang CM, Lu HS, Wu XY, Wang C, Guang GX, Zhang JZ, Zheng $\mathrm{CH}$. Surgical treatment and prognosis of gastric cancer in 2,613 patients. World $\mathrm{J}$ Gastroenterol. 2004;10:3405-8. 